\title{
Anaplastic lymphoma kinase in human cancer
}

\author{
Antonella Barreca ${ }^{1}$, Elena Lasorsa ${ }^{1}$, Ludovica Riera ${ }^{1}$, Rodolfo Machiorlatti ${ }^{1}$, Roberto Piva ${ }^{1,2}$, \\ Maurilio Ponzoni ${ }^{3}$, Ivo Kwee ${ }^{4}$, Francesco Bertoni ${ }^{4}$, Pier Paolo Piccaluga ${ }^{5}$, Stefano A Pileri ${ }^{5}$, \\ Giorgio Inghirami ${ }^{1,2}$ and The European T-Cell Lymphoma Study Group ${ }^{\dagger}$ \\ ${ }^{1}$ Department of Pathology and Center for Experimental Research and Medical Studies (CeRMS), University of Torino, Via Santena 7, Torino 10126, Italy \\ ${ }^{2}$ Department of Pathology, NYU Cancer Center, New York University School of Medicine, New York, New York 10016, USA \\ ${ }^{3}$ Unit of Lymphoid Malignancies, San Raffaele H Scientific Institute, Milan 20132, Italy, \\ ${ }^{4}$ Laboratory of Experimental Oncology and Lymphoma Unit, Oncology Institute of Southern Switzerland (IOSI), Bellinzona 6900, Switzerland \\ ${ }^{5}$ Hematopathology Section, Department of Hematology and Oncological Sciences 'L. and A. Seràgnoli', S. Orsola-Malpighi Hospital, University of Bologna, Bologna 40138, Italy \\ (Correspondence should be addressed to G Inghirami at Department of Pathology and Center for Experimental Research and Medical Studies (CeRMS), \\ University of Torino; Email: giorgio.inghirami@unito.it) \\ ${ }^{\dagger}$ See Acknowledgements section for details of the European T-Cell Lymphoma Study Group
}

\begin{abstract}
The receptor tyrosine kinases (RTKs) play a critical role, controlling cell proliferation, survival, and differentiation of normal cells. Their pivotal function has been firmly established in the pathogenesis of many cancers as well. The anaplastic lymphoma kinase (ALK), a transmembrane RTK, originally identified in the nucleophosmin (NPM)-ALK chimera of anaplastic large cell lymphoma, has emerged as a novel tumorigenic player in several human cancers. In this review, we describe the expression of the ALK-RTK, its related fusion proteins, and their molecular mechanisms of activation. Novel tailored strategies are briefly illustrated for the treatment of ALK-positive neoplasms.
\end{abstract}

Journal of Molecular Endocrinology (2011) 47, R11-R23

\section{Introduction}

Since the seminal description of the nucleophosmin (NPM)-anaplastic lymphoma kinase (ALK) fusion protein in anaplastic large cell lymphoma (ALCL; Morris et al. 1994, Shiota et al. 1994), many ALK chimeras have been described in inflammatory myofibroblastic tumors (IMTs; Griffin et al. 1999), diffuse large B-cell lymphoma (DLBCL; Arber et al. 1996), and more recently, in several epithelial neoplasms, including non-small cell lung cancer (NSCLC; Rikova et al. 2007, Soda et al. 2007), esophageal squamous cell carcinoma (SCG; Jazii et al. 2006, Du et al. 2007), colon (Lin et al. 2009), and breast carcinoma (Lin et al. 2009). ALK receptor expression, originally documented in a variety of cancer lines, has been documented in many neuronal tumors (Lamant $e t$ al. 2000, Miyake et al. 2002, 2005, Stoica et al. 2002, Osajima-Hakomori et al. 2005), glioblastoma (Powers et al. 2002, Shao et al. 2002, Grzelinski et al. 2005, Lu et al. 2005), and mesenchymal neoplasms including melanoma (Dirks et al. 2002) and rhabdomyosarcoma (Morris et al. 1994, 1997, Pulford et al. 1997, Falini et al. 1998, Cessna et al. 2002, Pillay et al. 2002, Li et al. 2004). In this context, ALK overexpression or gain of function mutations have been demonstrated to be tumorigenic.

\section{ALK expression in hematological disorders}

ALCL, first described in 1985 (Stein et al. 1985), nowadays corresponds to a specific subtype of systemic peripheral T-cell lymphoma (Swerdlow et al. 2008). Most ALCL display chromosomal translocations of the $A L K$ gene, although a subset, lacking these aberrations, is now recognized as a provisional entity (Swerdlow et al. 2008). ALK encodes a $210 \mathrm{kDa}$ tyrosine kinase (TK) receptor (CD247) belonging to the insulin growth factor receptor super family. It is expressed at high levels in the nervous system during embryogenesis but only focally in the adult brain (Iwahara et al. 1997). Its presence outside of the nervous system is believed to be negligible in normal tissues. Although the physiologic role of ALK receptor in mammals is unknown, it might 
be involved in neuronal differentiation, as suggested by its ability to induce neurite outgrowth in vitro (Souttou et al. 2001) and by its role in synapse formation in Caenorhabditis elegans and Drosophila melanogaster (Liao et al. 2004, Bazigou et al. 2007, Reiner et al. 2008).

Remarkably, Allouche (2007) has recently demonstrated that ALK (CD246) is a novel dependence receptor. Indeed, the ALK receptor is inactive in the absence of engaging ligand(s) and its expression results in enhanced apoptosis, whereas ALK activation, via a ligand-mediated engagement or as result of ALK fusion proteins, decreases apoptosis (Mourali et al. 2006).

Virtually, all ALK chimeras derive from genomic breakpoints, almost invariably located within the intron between the exons 19 and 20 (NM_004304.3), leading to the fusion of the intracytoplasmic domain of ALK (exons 20-29) with different partners, which provide dimerization domains (Chiarle et al. 2008, Fornari et al. 2009).

Many ALK-positive $\left(\mathrm{ALK}^{+}\right)$ALCL express the NPMALK fusion protein, derived from the $\mathrm{t}(2 ; 5)(\mathrm{p} 23 ; \mathrm{q} 25)$ translocation (Jaffe et al. 2001). NPM1 is a multifunctional protein, which acts as a molecular chaperone in the transport of pre-ribosomal particles from the nucleus to the cytoplasm, although it plays a critical role in DNA repair, transcription, and genomic stability as well (Okuwaki 2008). The N-terminus domain of NPM1, within the ALK chimera, provides a dimerization domain, essential for chimera autophosphorylation, allowing the constitutive activation of the kinase and the firing of downstream signaling (Fujimoto et al. 1996, Bischof et al. 1997, Chiarle et al. 2008).

The oncogenic potential of ALK chimeras was first demonstrated in vivo in mice undergoing bone marrow transplantation with cells transduced with NPM-ALK construct (Kuefer et al. 1997). Similar results were obtained testing the transforming potential of fibroblasts containing NPM-ALK in vitro (Bai et al. 1998). In 2003, a mouse model was generated in which the expression of NPM-ALK, under the control of the CD4 promoter (Chiarle et al. 2003), showed the spontaneous development of T-cell lymphomas and/or plasmacytomas, confirming the lymphomagenic role of NPM-ALK, providing a valuable tool for the study of ALCL. These findings were then confirmed using additional mouse models (Turner \& Alexander 2005).

Mutagenesis and functional studies have identified several NPM-ALK interacting molecules such as PLC- $\gamma$, IRS1, HSP90, GRB2, SHCC, JAK2/JAK3, PI3K, and STAT3/5 (Chiarle et al. 2008; Fig. 1).

\section{Phospholipase $\mathrm{C}-\gamma$}

NPM-ALK controls cellular proliferation via the phospholipase $\mathrm{C}-\gamma$ (PLC- $\gamma$ ) docking in position Y664 of NPM-ALK. PLC- $\gamma$ activation induces the hydrolysis of phosphatidylinositol $\left(\mathrm{PIP}_{2}\right)$ into inositol triphosphate $\left(\mathrm{IP}_{3}\right)$ and diacylglycerol (DAG), molecules that can modulate the release of $\mathrm{Ca}^{2+}$ from intracellular compartments and activate the serine/threonine protein kinase $\mathrm{C}$ (PKC). Ba/F3 cells (a pro-B line that requires IL3 for survival and growth) can grow in IL3independent manner following the NPM-ALK transfection, while the use of the NPM-ALK ${ }^{\mathrm{Y} 664 \mathrm{~F}}$ mutant completely disables their growth in the absence of IL3 (Bai et al. 1998).

\section{RAS}

$\mathrm{ALK}^{+}$ALCL cell growth is largely dependent on the Rasextracellular signal regulated kinase (ERK) pathway. ALK fusion proteins can engage the effectors IRS1, SHC, and GRB2 lead to the constitutive activation of Ras. Although IRS1 and SHC may not be required for transformation (Fujimoto et al. 1996), inhibition of ERK-1 and -2 leads to cell cycle arrest and block of proliferation.

Ras activation via mitogen-activated protein kinases (MAPK), ERK-1, and -2 regulates the phosphorylation of several transcription factors, including the AP-1 complex, which is believed to contribute to the ALCL neoplastic phenotype (i.e. CD30).

\section{Phosphatidylinositol 3 kinase}

NPM-ALK interacts directly and indirectly with PI3K (Bai et al. 2000). Following this association, the PI3K catalytic subunit (p110) leads to the activation of the PKB/AKT pathway. AKT, a serine/threonine kinase, is known to provide anti-apoptotic signals regulating several mediators, including caspase 9, BAD, NF-kB, and Fas ligand (Chiarle et al. 2008). Moreover, AKT, through the hyperphosphorylation of the transcription factor FOXO3a (Gu et al. 2004), increases cyclin D2 and inhibits p27 transcription, forcing G1 phase cell cycle arrest.

\section{c-Src}

c-Src is a TK receptor that plays a relevant role in cell migration, as well as in cell proliferation and growth. Its kinase activity is essential for the integrin-mediated adhesion and for morphological adaptation of cells. c-Src is normally maintained in a catalytically inactive conformation by molecular interactions via its $\mathrm{SH} 2$ and SH3 domains. pp60 (c-Src) is activated by NPM-ALK following its association with a tyrosine residue in position 418. Studies taking advantage of Src-specific inhibitors or RNA interference have shown that NPM-ALK-mediated activation of c-Src kinase is important for the growth of NPM-ALK-positive ALCL cells. SRC-family kinases may also contribute to the activation of VAV1, which was directly activated by 


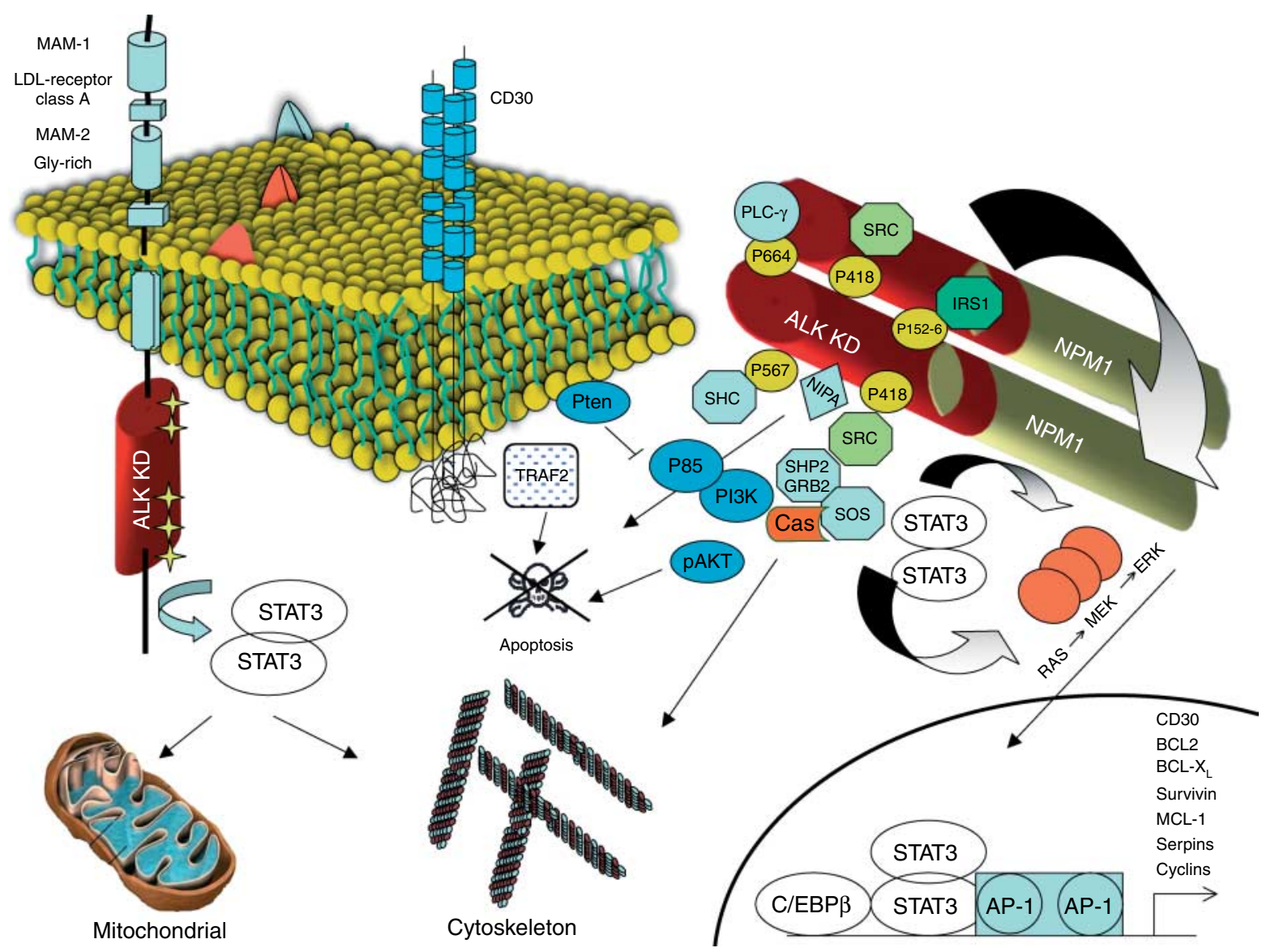

Figure $1 \mathrm{ALK}$ and its signaling transduction pathways. Mutated ALK-R and ALK fusion proteins (NPM-ALK is depicted as representative ALK chimera) can elicit multiple signaling pathways, which are responsible for cell transformation and for the maintenance of the neoplastic phenotype (Chiarle et al. 2008, Fornari et al. 2009). The ALK-RTK is a tyrosine kinase membrane receptor characterized by an extra-membraneous region, in which distinct domains/regions can be recognized (MAM-1 and -2 LDL-receptor class A, and glycine-rich region), a trans-membrane segment within the lipid bilayer, and an intracytoplasmic segment, which includes the tyrosine catalytic domain and its flanking regions. Several activating mutations of the ALK-RTK have been recently demonstrated within the juxtamembrane, P-loop, kinase domain and end of $\mathrm{C}$ helix, and catalytic/activation loops (some of the mutations within the catalytic domains are schematically represented here: stars). These activating mutations lead to the constitutive activation of the receptor in a ligand-independent manner. The kinase activation, in both mut-ALK-RTK and ALK chimeras, is associated with the docking of several adaptors, which in turn fire several signaling pathways. ALK-dependent mitogenic signaling is largely mediated via Ras/MAP kinase pathway through the direct binding of IRS1, SHC, and SRC on specific tyrosine residues within the intracytoplasmic segment of ALK. The SHP2/GRB2 complex interacts with p130Cas, modifying the cytoskeleton organization as well. In the case of ALK-driven phosphatidylinositol 3 kinase (PI3K) activation, a relevant anti-apoptotic signal is generated mainly through pAKT1/2, and its downstream molecules (inhibition of BAD and FOXO3a-mediated transcription). At the same time, the PI3K pathway controls cell cycle progression. An additional oncogenic signal may be provided by PLC- $\gamma$, which binds directly to activated ALK, and generating diacylglycerol and IP 3 activates PKC and mobilizes calcium stores from the endoplasmic reticulum. A critical oncogenic player is represented by the JAK/STAT3 pathway, which provides essential survival signals and modulates the cellular metabolism regulating the mitochondrial oxidation chain. STAT3 is activated by ALK either directly or through Jak. STAT3 activation is associated with distinct gene expression profile, which can distinguish ALCL from other T-cell neoplasms. The downstream effectors of STAT3 include several members of the BCL2 family (BCL2, $B C L-X_{L}$, and $M C L-1$ ) and anti-apoptotic proteins, i.e. survivin and multiple transcription factor (i.e. C/EBP $\beta$ ). Finally, ALK fusion proteins have been shown to upregulate, via Ras and AP-1 transcription factors, the expression of CD30, which provides anti-apoptotic signals through TRAF2.

NPM-ALK, leading to a sustained activation state of Cdc42 in ALCL cells (Ambrogio et al. 2008). Cdc42 regulates the shape and migration of ALCL cells and it is necessary for the growth and maintenance of lymphoma cells in vivo (Ambrogio et al. 2008).

\section{Signal transducers and activators of transcription}

Signal transducers and activators of transcription (STAT) proteins are a family of transcription factors first characterized for their role in cytokine signaling. 
These proteins contain a site for specific tyrosine phosphorylation, which after modification results in a conformational rearrangement and dimerization through phosphotyrosine-SH2 domain interactions (Levy \& Darnell 2002). Once STATs are phosphorylated, they dimerize and accumulate in the cell nucleus and bind to enhancer elements of target genes. Zamo et al. (2002) have first shown that STAT3 is the key effector molecule of the ALK-mediated signaling in ALCL and its activation is required for the maintenance of the neoplastic phenotype (Chiarle et al. 2005). NPM-ALK can directly phosphorylate STAT3 or can activate JAK3, which in turn can contribute to STAT3 activation (Chiarle et al. 2008). STAT3 phosphorylation results in an increased expression of BCL2, BCL- $\mathrm{X}_{\mathrm{L}}$, survivin, and MCL-1 proteins, involved in anti-apoptotic processes. STAT3-mediated signal also leads to an uncontrolled proliferation, acting on cell cycle regulators such as cyclin D3 and c-myc (Amin et al. 2003), often overexpressed in $\mathrm{ALK}^{+}$lymphoma (Chiarle et al. 2003). Cooperation between NPM-ALK and JAK/STAT pathway might also lead in certain context to the STAT5 activation (Nieborowska-Skorska et al. 2001), although in T-cell, STAT3 acts as a STAT5 repressor (Zhang et al. 2007).

\section{ALK fusion proteins}

In addition to NPM-ALK, many other fusion proteins can be expressed in ALCL, namely ALK lymphoma oligomerization partner on chromosome 17 (ALO17;
Cools et al. 2002), TRK-fused gene (TFG; Hernández et al. 1999, 2002), moesin (MSN; Tort et al. 2001), tropomyosin 3 and 4 (TPM3 and TPM4; Lamant et al. 1999, Siebert et al. 1999, Meech et al. 2001), 5-aminoimidazole-4-carboxamide ribonucleotide formyltransferase/IMP cyclohydrolase (ATIC; Colleoni et al. 2000, Ma et al. 2000, Trinei et al. 2000), nonmuscle myosin heavy chain (MYH9; Lamant et al. 2003), and clathrin heavy chain (CLTC-ALK; Touriol et al. 2000; Table 1).

Virtually, all chimeras have the same ALK intracytoplasmic segment, but they show minor differences in the activation of several intracellular mediators, conceivably as a result of their different/unique subcellular compartmentalization and/or specific substrate interaction(s). Nevertheless, ALK fusion proteins share many common features: i) the transcription of the chimeric protein is driven by an ectopic/partner promoter; ii) the localization of these proteins is largely determined by the N-terminus partner region; iii) the presence of an oligomerization domain by the ALK partner protein, which induces the autophosphorylation and activation of the ALK kinase domain (Bischof et al. 1997, Mason et al. 1998).

Since the NPM-ALK shows a typical nuclear and cytoplasmic subcellular localization, the absence of nuclear ALK staining suggests the presence of ALK variant proteins (Kinney \& Kadin 1999, Morris et al. 2001, Pulford et al. 2005). Indeed, the systematic application of ALK-specific antibodies has a critical

Table 1 Chromosomal translocations involving anaplastic lymphoma kinase gene in cancers

\begin{tabular}{|c|c|c|c|}
\hline Disease & Fusion protein & Chromosomal abnormality & Principal references \\
\hline ALCL & NPM-ALK & $\mathrm{t}(2 ; 5)(p 23 ; q 35)$ & Morris et al. (1994) and Shiota et al. (1994) \\
\hline ALCL & ALO17-ALK & $\mathrm{t}(2 ; 17)(\mathrm{p} 23 ; q 25)$ & Cools et al. (2002) \\
\hline ALCL & MSN-ALK & $\mathrm{t}(2 ; \mathrm{X})(\mathrm{p} 32 ; \mathrm{q} 11-12)$ & Tort et al. $(2001,2004)$ \\
\hline ALCL & TPM3-ALK & $\mathrm{t}(1 ; 2)(\mathrm{q} 25 ; \mathrm{p} 23)$ & Lamant et al. (1999) and Siebert et al. (1999) \\
\hline ALCL & TPM4-ALK & $t(2 ; 19)(p 23 ; p 13)$ & Meech et al. (2001) \\
\hline ALCL & CLTC-ALK & $\mathrm{t}(2 ; 17)(\mathrm{p} 23 ; q 23)$ & Touriol et al. (2000) \\
\hline IMT & TPM3-ALK & $t(1 ; 2)(q 25 ; p 23)$ & Lawrence et al. (2000) \\
\hline IMT & TPM4-ALK & $t(1 ; 19)(p 23 ; p 13)$ & Lawrence et al. (2000) \\
\hline IMT & CLTC-ALK & $t(2 ; 17)(p 23 ; q 23)$ & Bridge et al. (2001) and Patel et al. (2007) \\
\hline IMT & ATIC-ALK & $\operatorname{inv}(2)(p 23 ; q 35)$ & Debiec-Rychter et al. (2003) \\
\hline IMT & SEC31L1-ALK & $\mathrm{t}(2 ; 4)(\mathrm{p} 23 ; \mathrm{q} 21)$ & Panagopoulos et al. (2006) \\
\hline DLBCL & CLTC-ALK & $\mathrm{t}(2 ; 17)(\mathrm{p} 23 ; \mathrm{q} 23)$ & De Paepe et al. (2003) \\
\hline DLBCL & Unknown & ins(3'ALKK)(4q22-24) & Stachurski et al. (2007) \\
\hline DLBCL & SQSTM1-ALK & $\mathrm{t}(2 ; 5)(\mathrm{p} 23 \cdot 1 ; \mathrm{q} 35 \cdot 3)$ & Takeuchi et al. (2010) \\
\hline DLBCL & SEC31A-ALK & ins $(4)(2 ; 4)(? ; q 21) t(2 ; 4)(p 24 ; q 21)$ & Bedwell et al. (2010) and Van Roosbroeck et al. (2010) \\
\hline SCC & TPM4-ALK & $t(2 ; 19)(p 23 ; p 13)$ & Du et al. (2007) and Jazii et al. (2006) \\
\hline $\mathrm{RCC}$ & VCL-ALK & $t(2 ; 10)(p 23 ; q 22)$ & Debelenko et al. (2010) \\
\hline
\end{tabular}


role for the appropriate classification of ALCL, demonstrating that $\sim 60-80 \%$ of all ALCL are $\mathrm{ALK}^{+}$ (Webb et al. 2009). It is important to underline that $\mathrm{ALK}^{-}$ALCL are indistinguishable from $\mathrm{ALK}^{+}$ALCL using morphological criteria alone. Therefore, the expression of ALK has become a key factor, not only for a proper diagnosis, but also for the precise ALCL stratification, providing relevant prognostic and therapeutic information. Since ALCL share a distinct gene expression profile, it has been postulated a putative common origin and/or common transformation pathway(s) for all ALCL (Piva et al. 2010). A single ALK lesion, although essential for transformation, requires additional genetic defects, which are however yet to be determined. The actual impact of insect bites in the pathogenesis of $\mathrm{ALK}^{+}$ALCL remains to be elucidated (Fornari et al. 2009, Lamant et al. 2010).

Interestingly, as underlined in the fourth edition of the WHO classification (Swerdlow et al. 2008), both $\mathrm{ALK}^{+}$and $\mathrm{ALK}^{-}$ALCL are characterized by frequent diffusion through sinuses and a cohesive growth pattern that can mimic metastatic carcinoma in the lymph node. They consist of very large lymphomatous elements (up to $60 \mu \mathrm{m}$ ) that in the $\mathrm{ALK}^{+}$tumors usually acquire a kidney- or horseshoe-shaped nuclear profile that justifies the term 'hallmark cells'. Besides the classical type, almost exclusively formed by large cells with a few reactive elements, ALK $^{+}$ALCL display some morphological variants: lympho-histiocytic, small cell, mixed, and Hodgkin-like cells. Under these circumstances, the expression of ALK by the neoplastic cells is of paramount importance for the distinction of the process from a hyperimmune reaction, PTCL-NOS, and nodular sclerosing Hodgkin lymphoma respectively. It is still a matter of debate whether similar variants are also observed in the setting of $\mathrm{ALK}^{-}$ALCL: possibly the lympho-histiocytic and Hodgkin-like ones do occur, although their recognition require negativity for PAX5/BSAP and occurrence of T-cell markers and possible clonal TCR rearrangements.

$\mathrm{ALK}^{+}$ALCL most frequently occur in the first decades of life with a typical male preponderance, although $\mathrm{ALK}^{+}$ALCL can also be seen in older individual at lower frequency; while $\mathrm{ALK}^{-}$ALCL arise most commonly in older patients (peak of incidence in the sixth decade) with a lower male preponderance (Shiota et al. 1995, Falini et al. 1999, Stein et al. 2000, Savage et al. 2008). ALK ${ }^{+}$ALCL patients have longer disease-free survival and better overall survival (OS) than $\mathrm{ALK}^{-}$cases (5 year OS: $70-80$ vs $33-49 \%$ ) following CHOP-based chemotherapy (Brugières et al. 1998, 2000, Falini et al. 1999, Stein et al. 2000, Williams et al. 2002, Savage et al. 2008), although these differences disappear if ALCL patients are stratified by stage (Savage et al. 2008).
Finally, it should be considered that the clinical outcome of ALCL is also influenced by the age of the patients, with a better survival in younger individuals. This may explain the more favorable clinical course of $\mathrm{ALK}^{+}$ALCL most frequently occurring in children and young adults.

Notably, an aberrant ALK expression has been detected in a minute subset of B-NHL (Delsol et al. 1997, Adam et al. 2003, Chikatsu et al. 2003, De Paepe et al. 2003, Gascoyne et al. 2003, Onciu et al. 2003, Reichard et al. 2007). ALK ${ }^{+}$DLBCL often carry the $\mathrm{t}(2 ; 17)$ translocation (Clathrin/ALK), while NPM-ALK or SEC31A-ALK proteins are less frequently expressed (Van Roosbroeck et al. 2010). Histologically, they display monomorphic, large immunoblastic/plasmablastic cells, which are CD138-, EMA-, CD4-, and cytoplasmic IgA- positive but lack CD30 and B-cellrestricted markers (Delsol et al. 1997, Reichard et al. 2007). $\mathrm{ALK}^{+}$DLBCL are characterized by an aggressive outcome and poor response to treatment (Reichard et al. 2007, Stachurski et al. 2007, Choung et al. 2008, Lee et al. 2008, Momose et al. 2009).

Finally, Chan et al. (2008) have described three cases of systemic histiocytosis, presenting in early infancy, expressing ALK or the TPM3-ALK chimeras. It is unclear whether these disorders are indeed true malignancies or due to an aberrant hyperproliferation of macrophages and dendritic cells, driven by the ectopic ALK expression.

\section{ALK expression in non-hematological disorders}

\section{ALK in mesenchymal neoplasms}

The IMTs are benign lesions of mesenchymal origin, composed of spindle cells, mixed with plasma cells and lymphocytes (Gleason \& Hornick 2008), originally thought to represent a reactive post-inflammatory condition rather than a neoplastic process (Umiker \& Iverson 1954). In 1999, Griffin et al. reported the first ALK gene rearrangements in these disorders. Further studies have subsequently documented the presence of different ALK-fusion proteins, all sharing the ALK kinase domain, fused to different partners, eventually leading to TPM4-ALK (Lawrence et al. 2000), ATIC-ALK (Debiec-Rychter et al. 2003), CLTC-ALK (Bridge et al. 2001, Patel et al. 2007), CARS-ALK (Cools et al. 2002, Debelenko et al. 2003), RANBP2-ALK (Ma et al. 2003), and SEC31L1-ALK (Panagopoulos et al. 2006) fusion proteins. It is believed that $35-60 \%$ of all IMTs display ALK rearrangements, which more often are seen in lesions of young individuals (Lawrence $e t a l$. 2000, Coffin et al. 2001, Cook et al. 2001). 
Among soft tissue tumors, Cessna et al. (2002) first reported two cases of rhabdomyosarcoma (RMS), with embryonal, alveolar features, and the NPM-ALK translocation. Subsequently, using an immunohistochemical approach, ALK expression was confirmed in $53 \%$ of alveolar RMS and 23\% of embryonal or unclassifiable RMS, which can display $A L K$ amplification (Corao et al. 2009).

\section{ALK and neural tumors}

Neuroblastoma is the most common extracranial solid tumor of childhood, derived from neural crest cells of the sympatho-adrenal lineage (Park et al. 2008). Although the clinical course of these patients is heterogeneous, many neuroblastomas are incurable, with poor long-term survival (Matthay et al. 1999), accounting for $15 \%$ of all pediatric oncology deaths (Maris et al. 2007).

Detectable levels of the ALK-receptor tyrosine kinase (RTK) were first described by Lamant et al. (2000) and subsequently high protein levels, due to $A L K$ amplification, were documented by several groups (Miyake et al. 2002, Osajima-Hakomori et al. 2005). In 2008, several groups have showed the presence of ALK mutations in inherited version (Janoueix-Lerosey et al. 2008, Mosse et al. 2008) as well as in sporadic (Caren et al. 2008, Chen et al. 2008, George et al. 2008, JanoueixLerosey et al. 2008, Mosse et al. 2008) neuroblastoma. The frequency of ALK mutations ranges from 4 to $8 \%$ in primary samples, and from 20 to $36 \%$ in neuroblastoma cell lines (Caren et al. 2008, Chen et al. 2008, George et al. 2008, Janoueix-Lerosey et al. 2008, Mosse et al. 2008). Notably, patients carrying mutated ALK-RTK or with over-expressed ALK-RTK have a poor prognosis (Caren et al. 2008, Chen et al. 2008, George et al. 2008, Janoueix-Lerosey et al. 2008, Mosse et al. 2008, Passoni et al. 2009).

Neuroblastoma-associated ALK-RTK mutations induce a constitutive activation of the receptor, which activates several downstream molecules (OsajimaHakomori et al. 2005) imposing a transformed phenotype. Indeed, the genetic (Mosse et al. 2008) or pharmacological inhibition of ALK-mutated species (George et al. 2008, McDermott et al. 2008) results in a decreased tumor growth. On the other hand, the role of wt-ALK-RTK remains elusive, since its expression might be simply linked to lineage constrains and/or unique neuronal differentiation stage(s) (Dirks et al. 2002).

Powers et al. (2002) first demonstrated that some primary glioblastoma and established cell lines expressed wt-ALK-RTK as well as pleiotrophin (PNT), an ALK-putative ligand. Glioblastoma often displays deregulated RTKs signaling, which plays a key role in their development and tumor outgrowth (Nister et al. 1991, Nishikawa et al. 1994). Interestingly, the ribozyme-mediated targeting of ALK was shown to reduce tumor growth of glioblastoma xenografts and increase apoptosis. Finally, the ablation of both PNT and ALK strongly enhances their individual antiproliferative effects (Grzelinski et al. 2009).

\section{ALK in epithelial cancers}

In the last decade, it has also become evident that many types of non-lymphoid tumors display a deregulated activation of $A L K$. This was first suggested by the work of Dirks et al. (2002), who originally documented the presence of ALK mRNA in many cancer cell lines derived from thyroid, small cell lung, breast carcinoma, and many other tumors.

Among epithelial cancers, lung tumors are the most common cause of cancer death in the world. Approximately, $85 \%$ of these neoplasms are represented by NSCLC, while $15 \%$ are recognized as small cell lung cancers (Jemal et al. 2004, Kamangar et al. 2006, Kelleher \& Mc Dermott 2010). In 2007, Soda et al. first reported a novel echinoderm microtubule-associated protein-like 4 (EML4)-ALK fusion protein in Japanese patients with NSCLC. Shortly thereafter, a second group, using a proteomic approach, described either EML4-ALK or TFG-ALK chimera in $\sim 4 \%$ of Chinese lung cancer patients (Rikova et al. 2007). Since then, many different EML4-ALK variants have been described (Rikova et al. 2007, Soda et al. 2007, Fukuyoshi et al. 2008, Inamura et al. 2008, Koivunen et al. 2008, Perner et al. 2008, Shinmura et al. 2008, Martelli et al. 2009, Wong et al. 2009). The frequency of EML4-ALK fusion ranges from $0 \cdot 1$ to $7 \cdot 5 \%$ (Fukuyoshi et al. 2008, Inamura et al. 2008, Koivunen et al. 2008, Perner et al. 2008, Shinmura et al. 2008, Martelli et al. 2009, Palmer et al. 2009, Wong et al. 2009), although Lin et al. (2009) and more recently Zhang et al. (2010) have detected a higher frequency of $\mathrm{ALK}^{+}$NSCLC, using highly sensitive approaches.

Finally, two different variants involving the KIF5B and $A L K$ genes have been described in a small subset of NSCLC (Takeuchi et al. 2009, Wong et al. 2011).

Collectively, these studies have pointed out the presence of several shared features among $\mathrm{ALK}^{+}$lung cancers: i) ALK fusions are mainly restricted to adenocarcinoma in patients with minimal or absent smoking story and young age of onset; ii) ALK rearrangements are mutually exclusive with other lung-associated genetic abnormalities such as EGFR and KRAS mutations; and iii) ALK translocations are not influenced by ethnic/racial differences, in contrast with EGFR mutations (Paez et al. 2004).

Notably, the univocal identification of ALK ${ }^{+}$NSCLC patients remains quite problematic. Indeed, the recognition of ALK translocations by FISH can be technically demanding and sometimes questionable. 
Similarly, the detection of ectopic ALK fusion proteins by immunohistochemistry is problematic as well (Inamura et al. 2008, Takeuchi et al. 2008, Martelli et al. 2009), and once FISH, immunohistochemistry, and RT-based approaches are combined, an overall consensus is reached in $80 \%$ of the cases (M Volante, personal communication, 24 November 2010). Moreover, normal lung epithelial and lymphoid cells can display ALK genetic lesions (Martelli et al. 2009, Sozzi et al. 2009).

ALK inhibitors, such as PF-2341066 or NPV-TAE-684 first in mouse models (Christensen et al. 2007, Galkin et al. 2007, Zou et al. 2007, McDermott et al. 2008, Soda et al. 2008) and more recently in clinical trials, have shown their therapeutic potential. Indeed, the data with crizotinib in a recent Phase II study have demonstrated an objective response rate of $57 \%$ and a disease control rate of $87 \%$ in NSCLC patients (Kwak et al. 2010). These findings are very impressive, although longer follow-up and different clinical trials may be required to conclusively assess the efficacy of a single drug regimen and its efficacy in naïve patients. Finally, the occurrence of ALK overriding resistance has to be precisely appraised and its molecular mechanism(s) dissected (Martinsson et al. 2010).

Perez-Pinera et al. (2007) first documented the ALK ectopic expression in a very large number of breast neoplasms, demonstrating detectable levels of ALK protein in normal breast epithelium and other nonepithelial elements by immunohistochemistry. Notably, the PNT knockdown in breast cancer cells can result in a decreased tumor growth in vitro (Fang et al. 1992, Garver et al. 1994, Riegel \& Wellstein 1994) and in vivo (Zhang et al. 1997). These findings suggested a pathogenetic role of the wt-ALK-RTK in this disease. Supporting findings have been provided by Lin et al. (2009), who have documented the presence of EML4-ALK transcripts in $\sim 2.5 \%$ of breast cancers and showed that ALK ablation leads to cell growth impairment. Analogous data have been generated in colon cancers (Lin et al. 2009) and very recently in renal cell carcinoma (Debelenko et al. 2010). The significance of ALK deregulation in breast and colon tumors remains unclear and its pathogenetic significance needs further confirmation (Fukuyoshi et al. 2008).

Finally, among epithelial cancers, squamous cell carcinoma (SCC) of the esophagus (SCCE) represents the sixth most common entity with the highest incidence rates in China, Iran, and developing countries. Deregulated ALK fusion proteins expression has been documented in SCCE, originally in Iranian patients by Jazii et al. (2006) and subsequently confirmed in a cohort of Chinese individuals (Du et al. 2007).

In conclusion, the list of solid neoplasms positive for ALK is continuously growing (i.e. prostate cancer, etc. E Medico and G Inghirami, personal communication).
These findings will definitively foster the execution of more frequent systematic molecular analyses and the development of reliable clinical diagnostic tests.

\section{Innovative therapeutic approaches for ALK tumors}

The ablation of ALK protein expression was originally obtained by ALK-specific small interfering RNA (siRNA) duplexes or selective ribozyme (Hubinger et al. 2003). These original studies showed that the ALK knockdown leads first to a cell cycle arrest, followed by massive apoptosis in vitro and/or in vivo (Piva et al. 2006). These original findings were first confirmed applying ALK-specific small molecules (Wan et al. 2006, Galkin et al. 2007) and more recently were supported by other novel ATP-competitive inhibitors (Li \& Morris 2008, Cheng \& Otte 2010). Since then, we have witnessed an increasing interest in this field, strongly encouraged by the discovery of a growing number of $\mathrm{ALK}^{+}$cancers (Li \& Morris 2008, Webb et al. 2009, Cheng \& Otte 2010). As a result, the first ALK inhibitor, PF-2341066, an ATP competitor, targeting both c-Met and ALK (Christensen et al. 2007), has recently reached the clinical arena in the treatment of $\mathrm{ALK}^{+}$NSCLC tumors, and other small molecules have just reached the clinics (LDK378) or are in pre-clinical stages (CEP28122, CEP37440, AP-26113, TAE-684, etc.). Meanwhile, several trials have also been opened for ALCL and neuroblastoma patients (http://www. ClinicalTrials.gov/). It is postulated that many compounds could soon reach the clinics (Webb et al. 2009, Cheng \& Otte 2010).

Since ALK signaling activates multiple downstream molecules, i.e. PI3K/AKT, JAK/STAT3 and 5, mTOR, and SRC, it is reasonable to speculate that several small molecules, targeting key effectors within these pathways, will be investigated in $\mathrm{ALK}^{+}$cancer patients. Considering the exquisite oncogenetic addition of $\mathrm{ALK}^{+}$ALCL to STAT3 (Piva et al. 2006), inhibition of this transcription factor could provide a novel therapeutic avenue. Nevertheless, because there is an enormous redundancy of signal transduction pathways in any given tumor, it is conceivable that we will be obliged to use disease/patient-specific cocktails to successfully knockdown multiple players among different pathways. This might be the case for those neoplasms displaying partial oncogenic addition to ALK and/or capable of executing counteracting resistant mechanisms. In this context, targeting EGFR, c-src, and MEK may also be considered. Finally, immunological strategies, in combination with conventional or small molecule approaches, could be considered to enhance anti-tumor responses or to gain the complete eradication of cancer cells. 


\section{Final remarks}

Since the original discovery by Morris et al. (1994) of the first ALK translocation, we have witnessed pivotal discoveries that led to a deeper understanding of the mechanisms leading to ALK-mediated transformation and tumor maintenance of ALCL. Now, a similar knowledge is mandatory for all other $\mathrm{ALK}^{+}$neoplasms. Dissecting this landscape is essential for the design of tailored therapies, for predicting therapeutic failures, and to overcome them. We hope that a dedicated effort will also be placed to fully understand the physiological role of the ALK receptor and to discover its ligand(s). Understanding the physiological role of ALK will be necessary for the development of clinical-grade diagnostic assays and for the design and implementation of immune-based therapeutic approaches.

\section{Declaration of interest}

The authors declare that there is no conflict of interest that could be perceived as prejudicing the impartiality of the research reported.

\section{Funding}

The study was supported by Associazione Italiana per la Ricerca sul Cancro (AIRC); Fondazione Guido Berlucchi; Ministero dell'Università e Ricerca Scientifica (MIUR); Regione Piemonte; Compagnia di San Paolo, Torino (Progetto Oncologia); and Oncosuisse Grant KLS02403-02-2009; Fondazione per la Ricerca e la Cura sui Linfomi (Lugano, Switzerland).

\section{Acknowledgements}

The European T-Cell Lymphoma Study Group: Italy: Antonella Barreca, Roberto Chiarle, Giuditta Cuccuru, Giorgio Inghirami, Barbara Martinoglio, Enzo Medico, Elisa Pellegrino, Roberto Piva, Maria Luisa Ruberto, Claudia Voena (University of Torino); Alessandro Fornari and Domenico Novero (ASO Molinette, and San Luigi Gonzaga Torino); Marco Chilosi and Alberto Zamó (University of Verona); Fabio Facchetti and Silvia Lonardi (University of Brescia); Anna De Chiara and Franco Fulciniti (National Cancer Institute, Napoli); Claudio Doglioni and Maurilio Ponzoni (San Raffaele Institute, Milano); Luca Agnelli, Antonino Neri and Katia Todoerti (University of Milan), Pier Paolo Piccaluga and Stefano Pileri (University of Bologna); Brunangelo Falini and Enrico Tiacci (University of Perugia), Belgium: Peter Van Loo, Thomas Tousseyn, and Christiane De Wolf-Peeters (University of Leuven), Germany: Eva Geissinger, Hans Konrad Muller-Hermelink and Andreas Rosenwald (University of Wuerzburg), Spain: Miguel Angel Piris and Maria E Rodriguez (Spanish National Cancer Research Centre, CNIO).

\section{References}

Adam P, Katzenberger T, Seeberger H, Gattenlohner S, Wolf J, Steinlein C, Schmid M, Muller-Hermelink HK \& Ott G 2003 A case of a diffuse large B-cell lymphoma of plasmablastic type associated with the $\mathrm{t}(2 ; 5)(\mathrm{p} 23 ; \mathrm{q} 35)$ chromosome translocation. American Journal of Surgical Pathology 27 1473-1476. (doi:10.1097/00000478200311000-00012)

Allouche M 2007 ALK is a novel dependence receptor. Cell Cycle 6 1533-1538. (doi:10.4161/cc.6.13.4433)

Ambrogio C, Voena C, Manazza AD, Martinengo C, Costa C, Kirchhausen T, Hirsh E, Inghirami G \& Chiarle R 2008 The anaplastic lymphoma kinase controls cell shape and growth of anaplastic large cell lymphoma through Cdc42 activation. Cancer Research 68 8899-8907. (doi:10.1158/0008-5472.CAN-08-2568)

Amin HM, Medeiros LJ, Ma Y, Feretzaki M, Das P, Leventaki V, Rassidakis GZ, O'Connor SL, McDonnell TJ \& Lai R 2003 Inhibition of JAK3 induces apoptosis and decreases anaplastic lymphoma kinase activity in anaplastic large cell lymphoma. Oncogene 22 5399-5407. (doi:10.1038/sj.onc.1206849)

Arber DA, Sun LH \& Weiss LM 1996 Detection of the $t(2 ; 5)(p 23 ; q 35)$ chromosomal translocation in large B-cell lymphomas other than anaplastic large cell lymphoma. Human Pathology 27 590-594. (doi:10.1016/S0046-8177(96)90167-7)

Bai RY, Dieter P, Peschel C, Morris SW \& Duyster J 1998 Nucleophosmin-anaplastic lymphoma kinase of large-cell anaplastic lymphoma is a constitutively active tyrosine kinase that utilizes phospholipase C-gamma to mediate its mitogenicity. Molecular and Cellular Biology 18 6951-6961.

Bai RY, Ouyang T, Miething C, Morris SW, Peschel C \& Duyster J 2000 Nucleophosmin-anaplastic lymphoma kinase associated with anaplastic large-cell anaplastic lymphoma activates the phosphatidylinositol 3-kinase/Akt antiapoptotic signaling pathway. Blood 96 4319-4327.

Bazigou E, Apitz H, Johansson J, Lorén CE, Hirst EM, Chen PL, Palmer RH \& Salecker I 2007 Anterograde Jelly belly and Alk receptor tyrosine kinase signaling mediates retinal axon targeting in Drosophila. Cell 128 961-975. (doi:10.1016/j.cell.2007.02.024)

Bedwell C, Rowe D, Moulton D, Jones G, Bown N \& Bacon CM 2010 Cytogenetically complex SEC31A-ALK fusions are recurrent in ALK-positive large B-cell lymphomas. Haematologia $96343-346$

Bischof D, Pulford K, Mason DY \& Morris SW 1997 Role of the nucleophosmin (NPM) portion of the non-Hodgkin's lymphomaassociated NPM-anaplastic lymphoma kinase fusion protein in oncogenesis. Molecular and Cellular Biology 17 2312-2325.

Bridge JA, Kanamori M, Ma Z, Pickering D, Hill DA, Lydiatt W, Lui MY, Colleoni GW, Antonescu CR, Ladanyi M et al. 2001 Fusion of the ALK gene to the clathrin heavy chain gene, CLTC, in inflammatory myofibroblastic tumor. American Journal of Pathology 159 411-415. (doi:10.1016/S0002-9440(10)61711-7)

Brugières L, Deley MC, Pacquement H, Meguerian-Bedoyan Z, Terrier-Lacombe MJ, Robert A, Pondarré C, Leverger G, Devalck C,

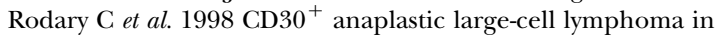
children: analysis of 82 patients enrolled in two consecutive studies of the French Society of Pediatric Oncology. Blood 92 3591-3598.

Brugières L, Quartier P, Le Deley MC, Pacquement H, Perel Y, Bergeron C, Schmitt C, Landmann J, Patte C, Terrier-Lacombe MJ et al. 2000 Relapses of childhood anaplastic large-cell lymphoma: treatment results in a series of 41 children - a report from the French Society of Pediatric Oncology. Annals of Oncology 11 53-58. (doi:10.1023/A:1008352726155)

Caren H, Abel F, Kogner P \& Martinsson T 2008 High incidence of DNA mutations and gene amplifications of the ALK gene in advanced sporadic neuroblastoma tumours. Biochemical Journal 416 153-159. (doi:10.1042/BJ20081834)

Cessna MH, Zhou H, Sanger WG, Perkins SL, Tripp S, Pickering D, Daines C \& Coffin CM 2002 Expression of ALK1 and p80 in inflammatory myofibroblastic tumor and its mesenchymal mimics: a study of 135 cases. Modern Pathology 15 931-938. (doi:10.1097/01. MP.0000026615.04130.1F) 
Chan JK, Lamant L, Algar E, Delsol G, Tsang WYW \& Lee KC 2008 $\mathrm{ALK}^{+}$histiocytosis: a novel type of systemic histiocytic proliferative disorder of early infancy. Blood 112 2965-2968. (doi:10.1182/blood2008-03-147017)

Chen Y, Takita J, Choi YL, Kato M, Ohira M, Sanada M, Wang L, Soda M, Kikuchi A, Igarashi T et al. 2008 Oncogenic mutations of ALK kinase in neuroblastoma. Nature 455 971-974. (doi:10.1038 nature07399)

Cheng M \& Otte GR 2010 Anaplastic lymphoma kinase as a therapeutic target in anaplastic large cell lymphoma, non-small cell lung cancer and neuroblastoma. Anti-Cancer Agents in Medicinal Chemistry 10 236-249.

Chiarle R, Gong JZ, Guasparri I, Pesci A, Cai J, Liu J, Simmons WJ, Dhall G, Howes J, Piva R et al. 2003 NPM-ALK transgenic mice spontaneously develop T-cell lymphomas and plasma cell tumors. Blood 101 1919-1927. (doi:10.1182/blood-2002-05-1343)

Chiarle R, Simmons WJ, Cai H, Dhall G, Zamo A, Raz R, Karras JG, Levy DE \& Inghirami G 2005 Stat3 is required for ALK-mediated lymphomagenesis and provides a possible therapeutic target. Nature Medicine 11 623-629. (doi:10.1038/nm1249)

Chiarle R, Voena C, Ambrogio C, Piva R \& Inghirami G 2008 The anaplastic lymphoma kinase in the pathogenesis of cancer. Nature Reviews. Cancer 8 11-23. (doi:10.1038/nrc2291)

Chikatsu N, Kojima H, Suzukawa K, Shinagawa A, Nagasawa T, Ozawa H, Yamashita Y \& Mori N 2003 ALK $^{+}, \mathrm{CD}^{-}{ }^{-}, \mathrm{CD}^{-} 0^{-}$large B-cell lymphoma containing anaplastic lymphoma kinase (ALK) fused to clathrin heavy chain gene (CLTC). Modern Pathology 16 828-832. (doi:10.1097/01.MP.0000081729.40230.1F)

Choung HS, Kim HJ, Kim WS, Kim K \& Kim SH 2008 Cytomorphology and molecular characterization of CLTC-ALK rearrangement in 2 cases of ALK-positive diffuse large B-cell lymphoma with extensive bone marrow involvement. Korean Journal of Laboratory Medicine $\mathbf{2 8}$ 89-94. (doi:10.3343/kjlm.2008.28.2.89)

Christensen JG, Zou HY, Arango ME, Li Q Lee JH, McDonnell SR, Yamazaki S, Alton GR, Mroczkowski B \& Los G 2007 Cytoreductive antitumor activity of PF-2341066, a novel inhibitor of anaplastic lymphoma kinase and c-Met, in experimental models of anaplastic large-cell lymphoma. Molecular Cancer Therapeutics 6 3314-3322. (doi:10.1158/1535-7163.MCT-07-0365)

Coffin CM, Patel A, Perkins S, Elenitoba-Johnson KS, Perlman E \& Griffin CA 2001 ALK1 and p80 expression and chromosomal rearrangements involving 2 p23 in inflammatory myofibroblastic tumor. Modern Pathology 14 569-576. (doi:10.1038/modpathol. 3880352)

Colleoni GW, Bridge JA, Garicochea B, Liu J, Filippa DA \& Ladanyi M 2000 ATIC-ALK: a novel variant ALK gene fusion in anaplastic large cell lymphoma resulting from the recurrent cryptic chromosomal inversion, inv(2) (p23q35). American Journal of Pathology 156 781-789. (doi:10.1016/S0002-9440(10)64945-0)

Cook JR, Dehner LP, Collins MH, Ma Z, Morris SW, Coffin CM \& Hill DA 2001 Anaplastic lymphoma kinase (ALK) expression in the inflammatory myofibroblastic tumor: a comparative immunohistochemical study. American Journal of Surgical Pathology 25 1364-1371. (doi:10.1097/00000478-200111000-00003)

Cools J, Wlodarska I, Somers R, Mentens N, Pedeutour F, Maes B, De Wolf-Peeters C, Pauwels P, Hagemeijer A \& Marynen P 2002 Identification of novel fusion partners of ALK, the anaplastic lymphoma kinase, in anaplastic large-cell lymphoma and inflammatory myofibroblastic tumor. Genes, Chromosomes and Cancer 34 354-362. (doi:10.1002/gcc.10033)

Corao DA, Biegel JA, Coffin CM, Barr FG, Wainwright LM, Ernst LM, Choi JK, Zhang PJ \& Pawel BR 2009 ALK expression in rhabdomyosarcomas: correlation with histologic subtype and fusion status. Pediatric and Developmental Pathology 12 275-283. (doi:10. 2350/08-03-0434.1)

Debelenko LV, Arthur DC, Pack SD, Helman LJ, Schrump DS \& Tsokos M 2003 Identification of CARS-ALK fusion in primary and metastatic lesions of an inflammatory myofibroblastic tumor. Laboratory Investigation 83 1255-1265. (doi:10.1097/01.LAB. 0000088856.49388.EA)

Debelenko L, Raimondi SC, Daw N, Shivakumar BR, Huang D, Nelson M \& Bridge JA 2010 Renal cell carcinoma with novel VCL-ALK fusion: new representative of ALK-associated tumor spectrum. Modern Pathology 24 430-442. (doi:10.1038/modpathol. 2010.213)

Debiec-Rychter M, Marynen P, Hagemeijer A \& Pauwels P 2003 ALK-ATIC fusion in urinary bladder inflammatory myofibroblastic tumor. Genes, Chromosomes and Cancer 38 187-190. (doi:10.1002/gcc. 10267)

Delsol G, Lamant L, Mariamé B, Pulford K, Dastugue N, Brousset P, Rigal-Huguet F, al Saati T, Cerretti DP, Morris SW et al. 1997 A new subtype of large B-cell lymphoma expressing the ALK kinase and lacking the 2;5 translocation. Blood 89 1483-1490.

De Paepe P, Baens M, van Krieken H, Verhasselt B, Stul M, Simons A, Poppe B, Laureys G, Brons P, Vandenberghe P et al. 2003 ALK activation by the CLTC-ALK fusion is a recurrent event in B-cell lymphoma. Blood 102 2638-2641. (doi:10.1182/blood-2003-041050)

Dirks WG, Fahnrich S, Lis Y, Becker E, MacLeod RA \& Drexler HG 2002 Expression and functional analysis of the anaplastic lymphoma kinase (ALK) gene in tumor cell lines. International Journal of Cancer 100 49-56. (doi:10.1002/ijc.10435)

Du XL, Hu H, Lin DC, Xia SH, Shen XM, Zhang Y, Luo ML, Feng YB, Cai Y, Xu X et al. 2007 Proteomic profiling of proteins dysregulated in Chinese esophageal squamous cell carcinoma. Journal of Molecular Medicine 85 863-875. (doi:10.1007/s00109-007-0159-4)

Falini B, Bigerna B, Fizzotti M, Pulford K, Pileri SA, Delsol G, Carbone A, Paulli M, Magrini U, Menestrina F et al. 1998 ALK expression defines a distinct group of $\mathrm{T} /$ null lymphomas with a wide morphological spectrum. American Journal of Pathology 153 875-886. (doi:10.1016/S0002-9440(10)65629-5)

Falini B, Pulford K, Pucciarini A, Carbone A, De Wolf-Peeters C, Cordell J, Fizzotti M, Santucci A, Pelicci PG, Pileri S et al. 1999 Lymphomas expressing ALK fusion protein(s) other than NPM-ALK. Blood 94 3509-3515.

Fang W, Hartmann N, Chow DT, Riegel AT \& Wellstein A 1992 Pleiotrophin stimulates fibroblasts and endothelial and epithelial cells and is expressed in human cancer. Journal of Biological Chemistry 267 25889-25897.

Fornari A, Piva R, Chiarle R, Novero D \& Inghirami G 2009 Anaplastic large cell lymphoma: one or more entities among T-cell lymphoma? Hematological Oncology 27 161-170. (doi:10.1002/hon.897)

Fujimoto J, Shiota M, Iwahara T, Seki N, Satoh H, Mori S \& Yamamoto T 1996 Characterization of the transforming activity of p80, a hyperphosphorylated protein in a Ki-1 lymphoma cell line with chromosomal translocation $\mathrm{t}(2 ; 5)$. PNAS 93 4181-4186. (doi:10.1073/pnas.93.9.4181)

Fukuyoshi Y, Inoue H, Kita Y, Utsunomiya T, Ishida T \& Mori M 2008 EML4-ALK fusion transcript is not found in gastrointestinal and breast cancers. British Journal of Cancer 98 1536-1539. (doi:10.1038/ sj.bjc.6604341)

Galkin AV, Melnick JS, Kim S, Hood TL, Li N, Li L, Xia G, Steensma R, Chopiuk G, Jiang J et al. 2007 Identification of NVP-TAE684, a potent, selective, and efficacious inhibitor of NPM-ALK. PNAS 104 270-275. (doi:10.1073/pnas.0609412103)

Garver RI Jr, Radford DM, Donis-Keller H, Wick MR \& Milner PG 1994 Midkine and pleiotrophin expression in normal and malignant breast tissue. Cancer 74 1584-1590. (doi:10.1002/10970142(19940901)74:5 < 1584::AID-CNCR2820740514>3.0.CO;2-V)

Gascoyne RD, Lamant L, Martin-Subero JI, Lestou VS, Harris NL, Müller-Hermelink HK, Seymour JF, Campbell LJ, Horsman DE, Auvigne I et al. 2003 ALK-positive diffuse large B-cell lymphoma is associated with clathrin-ALK rearrangements: report of six cases. Blood 102 2568-2571. (doi:10.1182/blood-2003-03-0786) 
George RE, Sanda T, Hanna M, Fröhling S, Luther W II, Zhang J, Ahn Y, Zhou W, London WB, McGrady P et al. 2008 Activating mutations in ALK provide a therapeutic target in neuroblastoma. Nature 455 975-978. (doi:10.1038/nature07397)

Gleason BC \& Hornick JL 2008 Inflammatory myofibroblastic tumours: where are we now? Journal of Clinical Pathology 61 428-437. (doi:10.1136/jcp.2007.049387)

Griffin CA, Hawkins AL, Dvorak C, Henkle C, Ellingham T \& Perlman EJ 1999 Recurrent involvement of 2p23 in inflammatory myofibroblastic tumors. Cancer Research 59 2776-2780.

Grzelinski M, Bader N, Czubayko F \& Aigner A 2005 Ribozymetargeting reveals the rate-limiting role of pleiotrophin in glioblastoma. International Journal of Cancer 117 942-951. (doi:10.1002/ijc. 21276)

Grzelinski M, Steinberg F, Martens T, Czubayko F, Lamszus K \& Aigner A 2009 Enhanced antitumorigenic effects in glioblastoma on double targeting of pleiotrophin and its receptor ALK. Neoplasia 11 145-156.

Gu TL, Tothova Z, Scheijen B, Griffin JD, Gilliland DG \& Sternberg DW 2004 NPM-ALK fusion kinase of anaplastic large-cell lymphoma regulates survival and proliferative signaling through modulation of FOXO3a. Blood 103 4622-4629. (doi:10.1182/blood2003-03-0820)

Hernández L, Pinyol M, Hernández S, Beà S, Pulford K, Rosenwald A, Lamant L, Falini B, Ott G, Mason DY et al. 1999 TRK-fused gene (TFG) is a new partner of ALK in anaplastic large cell lymphoma producing two structurally different TFG-ALK translocations. Blood 94 3265-3268.

Hernández L, Beà S, Bellosillo B, Pinyol M, Falini B, Carbone A, Ott G, Rosenwald A, Fernández A, Pulford K et al. 2002 Diversity of genomic breakpoints in TFG-ALK translocations in anaplastic large cell lymphomas: identification of a new TFG-ALK(XL) chimeric gene with transforming activity. American Journal of Pathology 160 1487-1494. (doi:10.1016/S0002-9440(10)62574-6)

Hubinger G, Wehnes E, Xue L, Morris SW \& Maurer U 2003 Hammerhead ribozyme-mediated cleavage of the fusion transcript NPM-ALK associated with anaplastic large-cell lymphoma. Experimental Hematology 31 226-233. (doi:10.1016/S0301472X(02)01084-6)

Inamura K, Takeuchi K, Togashi Y, Nomura K, Ninomiya H, Okui M, Satoh Y, Okumura S, Nakagawa K, Soda M et al. 2008 EML4-ALK fusion is linked to histological characteristics in a subset of lung cancers. Journal of Thoracic Oncology 3 13-17. (doi:10.1097/JTO. 0b013e31815e8b60)

Iwahara T, Fujimoto J, Wen D, Cupples R, Bucay N, Arakawa T, Mori S, Ratzkin B \& Yamamoto T 1997 Molecular characterization of ALK, a receptor tyrosine kinase expressed specifically in the nervous system. Oncogene 14 439-449. (doi:10.1038/sj.onc.1200849)

Jaffe ES, Harris NL, Stein H \& Vardiman JW 2001 World Health Organization Classifications of Tumors: Pathology and Genetics of Tumors of the Haematopoietic and Lymphoid Tissues. Lyon: International Agency for Research on Cancer.

Janoueix-Lerosey I, Lequin D, Brugières L, Ribeiro A, de Pontual L, Combaret V, Raynal V, Puisieux A, Schleiermacher G, Pierron G et al. 2008 Somatic and germline activating mutations of the ALK kinase receptor in neuroblastoma. Nature $\mathbf{4 5 5}$ 967-970. (doi:10. 1038/nature07398)

Jazii FR, Najafi Z, Malekzadeh R, Conrads TP, Ziaee AA, Abnet C, Yazdznbod M, Karkhane AA \& Salekdeh GH 2006 Identification of squamous cell carcinoma associated proteins by proteomics and loss of $\beta$ tropomyosin expression in esophageal cancer. World Journal of Gastroenterology 12 7104-7112.

Jemal A, Clegg LX, Ward E, Ries LA, Wu X, Jamison PM, Wingo PA, Howe HL, Anderson RN \& Edwards BK 2004 Annual report to the nation on the status of cancer, 1975-2001, with a special feature regarding survival. Cancer 101 3-27. (doi:10.1002/cncr.20288)

Kamangar F, Dores GM \& Anderson WF 2006 Patterns of cancer incidence, mortality, and prevalence across five continents: defining priorities to reduce cancer disparities in different geographic regions of the world. Journal of Clinical Oncology 24 2137-2215. (doi:10.1200/JCO.2005.05.2308)

Kelleher FC \& Mc Dermott R 2010 The emerging pathogenic and therapeutic importance of the anaplastic lymphoma kinase gene. European Journal of Cancer 46 2357-2368. (doi:10.1016/j.ejca.2010. 04.006)

Kinney MC \& Kadin ME 1999 The pathologic and clinical spectrum of anaplastic large cell lymphoma and correlation with ALK gene dysregulation. American Journal of Clinical Pathology 111 S56-S67.

Koivunen JP, Mermel C, Zejnullahu K, Murphy C, Lifshits E, Holmes AJ, Choi HG, Kim J, Chiang D, Thomas R et al. 2008 EML4-ALK fusion gene and efficacy of an ALK kinase inhibitor in lung cancer. Clinical Cancer Research 14 4275-4283. (doi:10.1158/1078-0432. CCR-08-0168)

Kuefer MU, Look AT, Pulford K, Behm FG, Pattengale PK, Mason DY \& Morris SW 1997 Retrovirus-mediated gene transfer of NPM-ALK causes lymphoid malignancy in mice. Blood 90 2901-2910.

Kwak EL, Bang YJ, Camidge DR, Shaw AT, Solomon B, Maki RG, Ou SH, Dezube BJ, Jänne PA, Costa DB et al. 2010 Anaplastic lymphoma kinase inhibition in non-small-cell lung cancer. New England Journal of Medicine 18 1693-1703. (doi:10.1056/NEJMoa1006448)

Lamant L, Dastugue N, Pulford K, Delsol G \& Mariame BA 1999 A new fusion gene TPM3-ALK in anaplastic large cell lymphoma created by a $(1 ; 2)(\mathrm{q} 25 ; \mathrm{p} 23)$ translocation. Blood 93 3088-3095.

Lamant L, Pulford K, Bischof D, Morris SW, Mason DY, Delsol G \& Mariame B 2000 Expression of the ALK tyrosine kinase gene in neuroblastoma. American Journal of Pathology 156 1711-1721. (doi:10.1016/S0002-9440(10)65042-0)

Lamant L, Gascoyne RD, Duplantier MM, Armstrong F, Raghab A, Chhanabhai M, Rajcan-Separovic E, Raghab J, Delsol G \& Espinos E 2003 Non-muscle myosin heavy chain (MYH9): a new partner fused to ALK in anaplastic large cell lymphoma. Genes, Chromosomes and Cancer 37 427-432. (doi:10.1002/gcc.10232)

Lamant L, Pileri S, Sabattini E, Brugières L, Jaffe ES \& Delsol G 2010 Cutaneous presentation of ALK-positive anaplastic large cell lymphoma following insect bites: evidence for an association in five cases. Haematologia 95 449-455. (doi:10.3324/haematol.2009. 015024)

Lawrence B, Perez-Atayde A, Hibbard MK, Rubin BP, Dal Cin P, Pinkus JL, Pinkus GS, Xiao S, Yi ES, Fletcher CD et al. 2000 TPM3-ALK and TPM4-ALK oncogenes in inflammatory myofibroblastic tumors. American Journal of Pathology 157 377-384. (doi:10.1016/S00029440(10)64550-6)

Lee HW, Kim K, Kim W \& Ko YH 2008 ALK-positive diffuse large B-cell lymphoma: report of three cases. Hematological Oncology 26 108-113. (doi:10.1002/hon.841)

Levy DE \& Darnell JE Jr 2002 Stats: transcriptional control and biological impact. Nature Reviews. Molecular Cell Biology 3 651-662. (doi:10.1038/nrm909)

Li R \& Morris SW 2008 Development of anaplastic lymphoma kinase (ALK) small-molecule inhibitors for cancer therapy. Medicinal Research Reviews 28 372-412. (doi:10.1002/med.20109)

Li XQ, Hisaoka M, Shi DR, Zhu XZ \& Hashimoto H 2004 Expression of anaplastic lymphoma kinase in soft tissue tumors: an immunohistochemical and molecular study of 249 cases. Human Pathology 35 711-721. (doi:10.1016/j.humpath.2003.12.004)

Liao E, Hung W, Abrams B \& Zhen M 2004 An SCF-like ubiquitin ligase complex that controls presynaptic differentiation. Nature $\mathbf{4 3 0}$ 345-350. (doi:10.1038/nature02647)

Lin E, Guan Y, Soriano R, Rivers CS, Mohan S, Pandita A, Tang J \& Modrusan Z 2009 Exon array profiling detects EML4-ALK fusion in breast, colorectal, and non-small cell lung cancers. Molecular Cancer Research 7 1466-1476. (doi:10.1158/1541-7786.MCR-080522)

Lu KV, Jong KA, Kim GY, Singh J, Dia EQ, Yoshimoto K, Wang MY, Cloughesy TF, Nelson SF \& Mischel PS 2005 Differential induction 
of glioblastoma migration and growth by two forms of pleiotrophin. Journal of Biological Chemistry 280 26953-26964. (doi:10.1074/jbc. M502614200)

Ma Z, Cools J, Marynen P, Cui X, Siebert R, Gesk S, Schlegelberger B, Peeters B, De Wolf-Peeters C, Wlodarska I et al. 2000 $\operatorname{Inv}(2)$ (p23q35) in anaplastic large-cell lymphoma induces constitutive anaplastic lymphoma kinase (ALK) tyrosine kinase activation by fusion to ATIC, an enzyme involved in purine nucleotide biosynthesis. Blood 95 2144-2149.

Ma Z, Hill DA, Collins MH, Morris SW, Sumegi J, Zhou M, Zuppan C \& Bridge JA 2003 Fusion of ALK to the Ran-binding protein 2 (RANBP2) gene in inflammatory myofibroblastic tumor. Genes, Chromosomes and Cancer 37 98-105. (doi:10.1002/gcc.10177)

Maris JM, Hogarty MD, Bagatell R \& Cohn SL 2007 Neuroblastoma. Lancet 369 2106-2120. (doi:10.1016/S0140-6736(07)60983-0)

Martelli MP, Sozzi G, Hernandez L, Pettirossi V, Navarro A, Conte D, Gasparini P, Perrone F, Modena P, Pastorino U et al. 2009 EML4-ALK rearrangement in non-small cell lung cancer and nontumor lung tissues. American Journal of Pathology 174 661-670. (doi:10.2353/ajpath.2009.080755)

Martinsson T, Eriksson T, Abrahamsson J, Caren H, Hansson M, Kogner P, Kamaraj S, Schonherr C, Weinmar J, Ruuth K et al. 2010 Appearance of the novel activating F1174S ALK mutation in neuroblastoma correlaates with aggressive tumor progression and unresponsiveness to therapy. Cancer Research 71 98-105. (doi:10. 1158/0008-5472.CAN-10-2366)

Mason DY, Pulford KA, Bischof D, Kuefer MU, Butler LH, Lamant L, Delsol G \& Morris SW 1998 Nucleolar localization of the nucleophosmin-anaplastic lymphoma kinase is not required for malignant transformation. Cancer Research $\mathbf{5 8}$ $1057-1062$.

Matthay KK, Villablanca JG, Seeger RC, Stram DO, Harris RE, Ramsay NK, Swift P, Shimada H, Black CT, Brodeur GM et al. 1999 Treatment of high-risk neuroblastoma with intensive chemotherapy, radiotherapy, autologous bone marrow transplantation, and 13-cis-retinoic acid. Children's Cancer Group. New England Journal of Medicine 341 1165-1173. (doi:10.1056/ NEJM199910143411601)

McDermott U, Iafrate AJ, Gray NS, Shioda T, Classon M, Maheswaran S, Zhou W, Choi HG, Smith SL, Dowell L et al. 2008 Genomic alterations of anaplastic lymphoma kinase may sensitize tumors to anaplastic lymphoma kinase inhibitors. Cancer Research 68 3389-3395. (doi:10.1158/0008-5472.CAN-07-6186)

Meech SJ, McGavran L, Odom LF, Liang X, Meltesen L, GumpJ, Wei Q Carlsen S \& Hunger SP 2001 Unusual childhood extramedullary hematologic malignancy with natural killer cell properties that contains tropomyosin 4-anaplastic lymphoma kinase gene fusion. Blood 98 1209-1216. (doi:10.1182/blood.V98.4.1209)

Miyake I, Hakomori Y, Shinohara A, Gamou T, Saito M, Iwamatsu A \& Sakai R 2002 Activation of anaplastic lymphoma kinase is responsible for hyperphosphorylation of ShcC in neuroblastoma cell lines. Oncogene 21 5823-5834. (doi:10.1038/sj.onc.1205735)

Miyake I, Hakomori Y, Misu Y, Nakadate H, Matsuura N, Sakamoto M \& Sakai R 2005 Domain-specific function of ShcC docking protein in neuroblastoma cells. Oncogene 24 3206-3215. (doi:10.1038/sj.onc. 1208523)

Momose S, Tamaru J, Kishi H, Mikata I, Mori M, Toyozumi Y \& Itoyama S 2009 Hyperactivated STAT3 in ALK-positive diffuse large B-cell lymphoma with clathrin-ALK fusion. Human Pathology 40 75-82. (doi:10.1016/j.humpath.2008.06.009)

Morris SW, Kirstein MN, Valentine MB, Dittmer KG, Shapiro DN, Saltman DL \& Look AT 1994 Fusion of a kinase gene, ALK, to a nucleolar protein gene, NPM, in non-Hodgkin's lymphoma. Science 263 1281-1284. (doi:10.1126/science.8122112)

Morris SW, Naeve C, Mathew P, James PL, Kirstein MN, Cui X \& Witte DP 1997 ALK, the chromosome 2 gene locus altered by the $\mathrm{t}(2 ; 5)$ in non-Hodgkin's lymphoma, encodes a novel neural receptor tyrosine kinase that is highly related to leukocyte tyrosine kinase (LTK). Oncogene 14 2175-2188. (doi:10.1038/sj.onc. 1201062)

Morris SW, Xue L, Ma Z \& Kinney MC $2001 \mathrm{ALK}^{+} \mathrm{CD}^{+} 0^{+}$lymphomas: a distinct molecular genetic subtype of non-Hodgkin's lymphoma. British Journal of Haematology 113 275-295. (doi:10.1046/j.13652141.2001.02574.x)

Mosse YP, Laudenslager M, Longo L, Cole KA, Wood A, Attiyeh EF, Laquaglia MJ, Sennett R, Lynch JE, Perri P et al. 2008 Identification of ALK as a major familial neuroblastoma predisposition gene. Nature 455 930-935. (doi:10.1038/nature07261)

Mourali J, Bénard A, Lourenço FC, Monnet C, Greenland C, Moog-Lutz C, Racaud-Sultan C, Gonzalez-Dunia D, Vigny M, Delsol G et al. 2006 Anaplastic lymphoma kinase is a dependence receptor whose proapoptotic functions are activated by caspase cleavage. Molecular and Cellular Biology 26 6209-6222. (doi:10.1128) MCB.01515-05)

Nieborowska-Skorska M, Slupianek A, Xue L, Zhang Q, Raghunath PN, Hoser G, Wasik MA, Morris SW \& Skorski T 2001 Role of signal transducer and activator of transcription 5 in nucleophosmin/ anaplastic lymphoma kinase-mediated malignant transformation of lymphoid cells. Cancer Research 61 6517-6523.

Nishikawa R, Ji XD, Harmon RC, Lazar CS, Gill GN, Cavenee WK \& Huang HJ 1994 A mutant epidermal growth factor receptor common in human glioma confers enhanced tumorigenicity. PNAS 91 7727-7731. (doi:10.1073/pnas.91.16.7727)

Nister M, Claesson-Welsh L, Eriksson A, Heldin CH \& Westermark B 1991 Differential expression of platelet-derived growth factor receptors in human malignant glioma cell lines. Journal of Biological Chemistry 266 16755-16163.

Okuwaki M 2008 The structure and functions of NPM1/nucleophos$\mathrm{min} / \mathrm{B} 23$, a multifunctional nucleolar acidic protein. Journal of Biochemistry 143 441-448. (doi:10.1093/jb/mvm222)

Onciu M, Behm FG, Downing JR, Shurtleff SA, Raimondi SC, Ma Z, Morris SW, Kennedy W, Jones SC \& Sandlund JT 2003 ALK-positive plasmablastic B-cell lymphoma with expression of the NPM-ALK fusion transcript: report of 2 cases. Blood 102 2642-2644. (doi:10. 1182/blood-2003-04-1095)

Osajima-Hakomori Y, Miyake I, Ohira M, Nakagawara A, Nakagawa A \& Sakai R 2005 Biological role of anaplastic lymphoma kinase in neuroblastoma. American Journal of Pathology 167 213-222. (doi:10. 1016/S0002-9440(10)62966-5)

Paez JG, Janne PA, Lee JC, Tracy S, Greulich H, Gabriel S, Herman P, Kaye FJ, Lindeman N \& Boggon TJ 2004 EGFR mutations in lung cancer: correlation with clinical response to gefitinib therapy. Science 304 1497-1500. (doi:10.1126/science. 1099314)

Palmer R, Vernersson E, Grabbe C \& Hallberg B 2009 Anaplastic lymphoma kinase: signalling in development and disease. Biochemical Journal 420 345-361. (doi:10.1042/BJ20090387)

Panagopoulos I, Nilsson T, Domanski HA, Isaksson M, Lindblom P, Mertens F \& Mandahl N 2006 Fusion of the SEC31L1 and ALK genes in an inflammatory myofibroblastic tumor. International Journal of Cancer 118 1181-1186. (doi:10.1002/ijc.21490)

Park JR, Eggert A \& Caron H 2008 Neuroblastoma: biology, prognosis, and treatment. Pediatric Clinics of North America 55 97-120. (doi:10. 1016/j.pcl.2007.10.014)

Passoni L, Longo L, Collini L, Coluccia AML, Bozzi F, Podda M, Gregorio A, Gambini C, Garaventa A, Pistoia V et al. 2009 Mutationindependent anaplastic lymphoma kinase overexpression in poor prognosis neuroblastoma patients. Cancer Research 69 7338-7346. (doi:10.1158/0008-5472.CAN-08-4419)

Patel AS, Murphy KM, Hawkins AL, Cohen JS, Long PP, Perlman EJ \& Griffin CA 2007 RANBP2 and CLTC are involved in ALK rearrangements in inflammatory myofibroblastic tumors. Cancer Genetics and Cytogenetics 176 107-114. (doi:10.1016/j.cancergencyto. 2007.04.004) 
Perez-Pinera P, Chang Y, Astudillo A, Mortimer J \& Deuel TF 2007 Anaplastic lymphoma kinase is expressed in different subtypes of human breast cancer. Biochemical and Biophysical Research Communications 358 399-403. (doi:10.1016/j.bbrc.2007.04.137)

Perner S, Wagner PL, Demichelis F, Mehra R, Lafargue CJ, Moss BJ, Arbogast S, Soltermann A, Weder W, Giordano TJ et al. 2008 EML4-ALK fusion lung cancer: a rare acquired event. Neoplasia 10 298-302.

Pillay K, Govender D \& Chetty R 2002 ALK protein expression in rhabdomyosarcomas. Histopathology 41 461-467. (doi:10.1046/ j.1365-2559.2002.01534.x)

Piva R, Chiarle R, Manazza AD, Taulli R, Simmons W, Ambrogio C, D'Escamard V, Pellegrino E, Ponzetto C, Palestro G et al. 2006 Ablation of oncogenic ALK is a viable therapeutic approach for anaplastic large-cell lymphomas. Blood 107 689-697. (doi:10.1182/ blood-2005-05-2125)

Piva R, Agnelli L, Pellegrino E, Todoerti K, Grosso V, Tamagno I, Fornari A, Martinoglio B, Medico E, Zamò A et al. 2010 Gene expression profiling uncovers molecular classifiers for the recognition of anaplastic large-cell lymphoma within peripheral T-cell neoplasms. Journal of Clinical Oncology 28 1583-1590. (doi:10.1200/ JCO.2008.20.9759)

Powers C, Aigner A, Stoica GE, McDonnell K \& Wellstein A 2002 Pleiotrophin signaling through anaplastic lymphoma kinase is rate-limiting for glioblastoma growth. Journal of Biological Chemistry 277 14153-14158. (doi:10.1074/jbc.M112354200)

Pulford K, Lamant L, Morris SW, Butler LH, Wood KM, Stroud D, Delsol G \& Mason DY 1997 Detection of anaplastic lymphoma kinase (ALK) and nucleolar protein nucleophosmin (NPM)-ALK proteins in normal and neoplastic cells with the monoclonal antibody ALK1. Blood 89 1394-1404.

Pulford K, Roberton HM \& Jones M 2005 Antibody techiques used in the study of anaplastic lymphoma kinase-positive ALCL. Methods in Molecular Medicine 115 271-294. (doi:10.1385/1-59259-936-2:271)

Reichard KK, McKenna RW \& Kroft SH 2007 ALK-positive diffuse large B-cell lymphoma: report of four cases and review of the literature. Modern Pathology 20 310-319. (doi:10.1038/modpathol. 3800742)

Reiner DJ, Ailion M, Thomas JH \& Meyer BJ 2008 C. elegans anaplastic lymphoma kinase ortholog SCD-2 controls dauer formation by modulating TGF- $\beta$ signaling. Current Biology 18 1101-1109. (doi:10. 1016/j.cub.2008.06.060)

Riegel AT \& Wellstein A 1994 The potential role of the heparinbinding growth factor pleiotrophin in breast cancer. Breast Cancer Research and Treatment 31 309-314. (doi:10.1007/BF00666163)

Rikova K, Guo A, Zeng Q, Possemato A, Yu J, Haack H, Nardone J, Lee K, Reeves C, Li Y et al. 2007 Global survey of phosphotyrosine signaling identifies oncogenic kinases in lung cancer. Cell 131 1190-1203. (doi:10.1016/j.cell.2007.11.025)

Savage KJ, Harris NL, Vose JM, Ullrich F, Jaffe ES, Connors JM, Rimsza L, Pileri SA, Chhanabhai M, Gascoyne RD et al. 2008 $\mathrm{ALK}^{-}$anaplastic large-cell lymphoma is clinically and immunophentoypically different from both $\mathrm{ALK}^{+}$ALCL and peripheral T-cell lymphoma, not otherwise specified: report from the International Peripheral T-cell Lymphoma Project. Blood 111 5496-5504. (doi:10.1182/blood-2008-01-134270)

Shao CK, Su ZL, Feng ZY, Rao HL \& Tang LY 2002 Significance of ALK gene expression in neoplasms and normal tissues. Ai Zheng 21 $58-62$.

Shinmura K, Kageyama S, Tao H, Bunai T, Suzuki M, Kamo T, Takamochi K, Suzuki K, Tanahashi M, Niwa H et al. 2008 EML4-ALK fusion transcripts, but no NPM-, TPM3-, CLTC-, ATIC-, or TFG-ALK fusion transcripts, in non-small cell lung carcinomas. Lung Cancer 61 163-169. (doi:10.1016/j.lungcan.2007.12.013)

Shiota M, Fujimoto J, Semba T, Satoh H, Yamamoto T \& Mori S 1994 Hyperphosphorylation of a novel $80 \mathrm{kDa}$ protein-tyrosine kinase similar to Ltk in a human Ki-1 lymphoma cell line, AMS3. Oncogene 9 $1567-1574$.
Shiota M, Nakamura S, Ichinohasama R, Abe M, Akagi T, Takeshita M, Mori N, Fujimoto J, Miyauchi J, Mikata A et al. 1995 Anaplastic large cell lymphomas expressing the novel chimeric protein p80NPM/ALK: a distinct clinicopathologic entity. Blood $\mathbf{8 6}$ 1954-1960.

Siebert R, Gesk S, Harder L, Steinemann D, Grote W, Schlegelberger B, Tiemann M, Wlodarska I \& Schemmel V 1999 Complex variant translocation $\mathrm{t}(1 ; 2)$ with TPM3-ALK fusion due to cryptic ALK gene rearrangement in anaplastic large-cell lymphoma. Blood $\mathbf{9 4}$ 3614-3617.

Soda M, Choi YL, Enomoto M, Takada S, Yamashita Y, Ishikawa S, Fujiwara S, Watanabe H, Kurashina K \& Hatanaka H 2007 Identification of the transforming EML4-ALK fusion gene in nonsmall-cell lung cancer. Nature 448 561-566. (doi:10.1038/ nature 05945)

Soda M, Takada S, Takeuchi K, Choi YL, Enomoto M, Ueno T, Haruta H, Hamada T, Yamashita Y, Ishikawa Y et al. 2008 A mouse model for EML4-ALK-positive lung cancer. PNAS 105 19893-19897. (doi:10. 1073/pnas.0805381105)

Souttou B, Carvalho NB, Raulais D \& Vigny M 2001 Activation of anaplastic lymphoma kinase receptor tyrosine kinase induces neuronal differentiation through the mitogen-activated protein kinase pathway. Journal of Biological Chemistry 276 9526-9531. (doi:10.1074/jbc.M007333200)

Sozzi G, Martelli MP, Conte D, Modena P, Pettirossi V, Pileri SA \& Falini B 2009 The EML4-ALK but not the fusion protein can be expressed in reactive and neoplastic lymphoid tissues. Haematologia 94 1307-1311. (doi:10.3324/haematol.2009.008045)

Stachurski D, Miron PM, Al-Homsi S, Hutchinson L, Harris NL, Woda B \& Wang SA 2007 Anaplastic lymphoma kinase-positive diffuse large B-cell lymphoma with a complex karyotype and cryptic 3 ALK gene insertion to chromosome 4 q22-24. Human Pathology 38 940-945. (doi:10.1016/j.humpath.2006.12.019)

Stein H, Mason DY, Gerdes J, O'Connor N, Wainscoat J, Pallesen G, Gatter K, Falini B, Delsol G, Lemke H et al. 1985 The expression of the Hodgkin's disease associated antigen Ki-1 in reactive and neoplastic lymphoid tissue: evidence that Reed-Sternberg cells and histiocytic malignancies are derived from activated lymphoid cells. Blood 66 848-858.

Stein H, Foss HD, Dürkop H, Marafioti T, Delsol G, Pulford K, Pileri S \& Falini B $2000 \mathrm{CD} 30\left(^{+}\right)$anaplastic large cell lymphoma: a review of its histopathologic, genetic, and clinical features. Blood 96 3681-3695.

Stoica GE, Kuo A, Powers C, Bowden ET, Sale EB, Riegel AT \& Wellstein A 2002 Midkine binds to anaplastic lymphoma kinase (ALK) and acts as a growth factor for different cell types. Journal of Biological Chemistry 277 35990-35999. (doi:10.1074/jbc. M205749200)

Swerdlow SH, Campo E, Harris NL, Jaffe ES, Pileri SA, Stein H, Thiele J \& Vardiman JW 2008 WHO Classification of Tumours of Haematopoietic and Lymphoid Tissues. Lyon: International Agency for Research on Cancer.

Takeuchi K, Lim Choi Y, Soda M, Inamura K, Togashi Y, Hatano S, Enomoto M, Takada S \& Yamashita Y 2008 Multiple reverse transcription-PCR screening for EML4-ALK in fusion transcripts. Clinical Cancer Research 14 6618-6624. (doi:10.1158/1078-0432. CCR-08-1018)

Takeuchi K, Choi YL, Togashi Y, Soda M, Hatano S, Inamura K, Takada S, Ueno T, Yamashita Y, Satoh Y et al. 2009 KIF5B-ALK, a novel fusion oncokinase identified by an immunohistochemistrybased diagnostic system for ALK-positive lung cancer. Clinical Cancer Research 15 3143-3149. (doi:10.1158/1078-0432.CCR-083248)

Takeuchi K, Soda M, Togashi Y, Ota Y, Sekiguchi Y, Hatano S, Asaka R, Noguchi M \& Mano H 2010 Identification of a novel fusion, SQSTM1-ALK, in ALK-positive large B-cell lymphoma. Haematologia 96 464-467. (doi:10.3324/haematol.2010.033514) 
Tort F, Pinyol M, Pulford K, Roncador G, Hernandez L, Nayach I, Kluin-Nelemans HC, Kluin P, Touriol C, Delsol G et al. 2001 Molecular characterization of a new ALK translocation involving moesin (MSN-ALK) in anaplastic large cell lymphoma. Laboratory Investigation 81 419-426.

Tort F, Campo E \& Pohlman B 2004 Heterogeneity of genomic breakpoints in MSN-ALK translocations in anaplastic large cell lymphoma. Human Pathology 35 1038-1041. (doi:10.1016/j.humpath.2004.05.006)

Touriol C, Greenland C, Lamant L, Pulford K, Bernard F, Rousset T, Mason DY \& Delsol G 2000 Further demonstration of the diversity of chromosomal changes involving 2p23 in ALK-positive lymphoma: 2 cases expressing ALK kinase fused to CLTCL (clathrin chain polypeptide-like). Blood 95 3204-3207.

Trinei M, Lanfrancone L, Campo E, Pulford K, Mason DY, Pelicci PG \& Falini B 2000 A new variant anaplastic lymphoma kinase (ALK)fusion protein (ATIC-ALK) in a case of ALK-positive anaplastic large cell lymphoma. Cancer Research 60 793-798.

Turner SD \& Alexander DR 2005 What have we learnt from mouse models of NPM-ALK-induced lymphomagenesis? Leukemia 19 1128-1134. (doi:10.1038/sj.leu.2403797)

Umiker WO \& Iverson L 1954 Postinflammatory tumors of the lung; report of four cases simulating xanthoma, fibroma, or plasma cell tumor. Journal of Thoracic Surgery 28 55-63.

Van Roosbroeck K, Cools J, Dierickx D, Thomas J, Vandenberghe P, Stul M, Delabie J, De Wolf-Peeters C, Marynen P \& Wlodarska I 2010 ALK-positive large B-cell lymphomas with cryptic SEC31A-ALK and NPM1-ALK fusions. Haematologia 95 509-513. (doi:10.3324/ haematol.2009.014761)

Wan W, Albom MS, Lu L, Quail MR, Becknell NC, Weinberg LR, Reddy DR, Holskin BP, Angeles TS, Underiner TL et al. 2006 Anaplastic lymphoma kinase activity is essential for the proliferation and survival of anaplastic large-cell lymphoma cells. Blood 107 1617-1623. (doi:10.1182/blood-2005-08-3254)

Webb TR, Slavish J, George RE, Look AT, Xue L, Jiang Q, Cui X, Rentrop WB \& Morris SW 2009 Anaplastic lymphoma kinase: role in cancer pathogenesis and small-molecule inhibitor development for therapy. Expert Review of Anticancer Therapy 9 331-356. (doi:10.1586/ 14737140.9.3.331)

Williams DM, Hobson R, Imeson J, Gerrard M, McCarthy K \& Pinkerton CR 2002 Anaplastic large cell lymphoma in childhood: analysis of 72 patients treated on The United Kingdom Children's Cancer Study Group chemotherapy regimens. British Journal of Haematology 117 812-820. (doi:10.1046/j.1365-2141.2002.03482.x)

Wong DW, Leung EL, So KK, Tam IY, Sihoe AD, Cheng LC, Ho KK, Au JS, Chung LP \& Pik Wong M 2009 The EML4-ALK fusion gene is involved in various histologic types of lung cancers from nonsmokers with wild-type EGFR and KRAS. Cancer 115 1723-1733. (doi:10.1002/cncr.24181)

Wong DW, Leung EL, Wong SK, Tin VP, Sihoe AD, Cheng LC, Au JS, Chung LP \& Wong MP 2011 A novel KIF5B-ALK variant in non-small cell lung cancer. Cancer. (doi:10.1002/cncr.25843)

Zamo A, Chiarle R, Piva R, Howes J, Fan Y, Chilosi M, Levy DE \& Inghirami G 2002 Anaplastic lymphoma kinase (ALK) activates Stat3 and protects haematopoietic cells from cell death. Oncogene 21 1038-1047. (doi:10.1038/sj.onc.1205152)

Zhang N, Zhong R, Wang ZY \& Deuel TF 1997 Human breast cancer growth inhibited in vivo by a dominant negative pleiotrophin mutant. Journal of Biological Chemistry 272 16733-16736. (doi:10. 1074/jbc.272.27.16733)

Zhang Q, Wang HY, Liu X \& Wasik MA 2007 STAT5A is epigenetically silenced by the tyrosine kinase NPM1-ALK and acts as a tumor suppressor by reciprocally inhibiting NPM1-ALK expression. Nature Medicine 13 1341-1348. (doi:10.1038/nm1659)

Zhang X, Zhang S, Yang X, Yang J, Zhou Q, Yin L, An S, Lin J, Chen S, Xie Z et al. 2010 Fusion of EML4 and ALK is associated with development of lung adenocarcinoma lacking EGFR and KRAS mutations and is correlated with ALK expression. Molecular Cancer 9 188-200. (doi:10.1186/1476-4598-9-188)

Zou HY, Li Q, Lee JH, Arango ME, McDonnell SR, Yamazaki S, Koudriakova TB, Alton G, Cui JJ, Kung PP et al. 2007 An orally available small-molecule inhibitor of c-Met, PF-2341066, exhibits cytoreductive antitumor efficacy through antiproliferative and antiangiogenic mechanisms. Cancer Research 67 4408-4417. (doi:10. 1158/0008-5472.CAN-06-4443)

Received in final form 28 March 2011

Accepted 18 April 2011

Made available online as an Accepted Preprint 18 April 2011 